\title{
Inhibiting Factors of Interorganizational Cost Management Complementary Study
}

\author{
Rafael Araújo Sousa Farias ${ }^{1,2}$, Valdirene Gasparetto ${ }^{2}$ \\ ${ }^{1}$ Department of Administrative Sciences, University of Brasília, Brasília, Brazil \\ ${ }^{2}$ Department of Accounting Sciences, Federal University of Santa Catarina, Florianópolis, Brazil \\ Correspondence: Rafael Araújo Sousa Farias, Universidade de Brasília, Campus Universitário Darcy Ribeiro, Prédio da \\ FACE, Programa de Pós-Graduação em Administração. CEP: 70910-900, Brasília-DF, Brazil. E-mail: \\ farias-rafael@hotmail.com
}

Received: May 23, 2016

Accepted: June 8, 2016

Online Published: July 6, 2016

doi:10.5539/ibr.v9n8p91

URL: http://dx.doi.org/10.5539/ibr.v9n8p91

\begin{abstract}
The research problem of this study is based on the discussion of inhibitors related Interorganizational Cost Management (IOCM). Taking on an inductive logic, the study's objective is exploratory by way of a qualitative approach, with the overall goal of analyzing which factors inhibit the applicability of Interorganizational Cost Management. This study is a complement and completion of the debate initiated by Farias (2016). Fifty-four surveys retrieved from the literature were analyzed, which demonstrate the difficulties faced by companies in managing costs in a cooperative manner. Analysis on these studies could illustrate the perceptions held by different businesses, and list the difficulties faced by them, leading to the identification of 30 inhibiting factors. The diversity of the same highlights the interdisciplinary nature, as well as complexity, of the phenomenon in question. The study chose to divide the inhibiting factors into three groups, which relate to the developmental stages of Interorganizational relationships (planning, start of operations and maturation), with the inhibitors present in the three stages. Inhibitory factors related to People were found to be most predominant; the implementation of Interorganizational approaches requires not only changes in processes, but also in the adaptation of organizational behavior on part of those involved. Thus, the application of IOCM cannot be seen as a technical approach, guided by technology and management programs alone, and companies need to overcome internal barriers.
\end{abstract}

Keywords: inhibitors, Interorganizational cost management, strategic cost management, supply chain

\section{Introduction}

The evolution of markets and the increasing complexity in supply chains led to the rise of new management techniques and new systems of information exchange among companies, growing beyond the internal environment and reaching Interorganizational relationships (Kulmala, Paranko, \& Uusi-Rauva, 2002). Interorganizational networks have emerged as a widespread alternative for business needs to be met; moreover, Interorganizational networks can be a viable option for companies that cannot compete individually or have difficulties in operating in the face of the current economic complexity (Wincent, 2008). Businesses should take a stand and coordinate relationships that will help them address these challenges, such as globalization, as an opportunity (Drucker, 1997).

Businesses can obtain a competitive advantage through Interorganizational Cost Management, the goal of which is to find solutions that have lower costs when compared to the sum of the costs of businesses acting individually (Kulmala et al., 2002). Cooper and Slagmulder (1999) explain that Interorganizational Cost Management is a structured approach to coordinating the activities of companies in a supply chain, aiming at reducing total network costs.

Studies concerning Interorganizational relationships say that this approach is a tool for businesses to grow in the market in which they operate, generating benefits for all those involved (Ellram, 1994; Ellram \& Siferd, 1998; Cooper \& Slagmulder, 1999; Ferrin \& Plank, 2002; LaLonde, 2003). Nevertheless, from an empirical point of view, there is a significant number of businesses that fail to participate in cooperative processes, and many networks are unable to consolidate their structures and management models (Sadowski \& Duysters, 2008; Pereira, Alves, \& Silva, 2010).

Ongoing research on IOCM has generated approaches and concepts which explain the advantages of acting collaboratively with members of the supply chain to manage costs (Munday, 1992; LaLonde \& Pohlen, 1996; Kulmala et al., 2002; Cooper \& Slagmulder, 1999, 2003a, 2003b) and explain the implementation steps of the approach (Ellram, 2002a; Cooper \& Slagmulder, 2003b). However, few studies discuss the difficulties and potential obstacles which may 
occur during the implementation process (Hakansson \& Snehota, 1995; Park \& Ungson, 2001; Bastl, Grubic, Templar, Harrison, \& Fan, 2010; Pereira et al., 2010).

In light of this, the inter-relationship is possible and IOCM is presented as an opportunity, but its application can be a difficult task. It is observed that, given the advantages it affords, it would be natural that most companies should seek the interrelationship; paradoxically, the opposite occurs (Kulmala et al., 2002). This situation is viewed as a research opportunity, thus, the question posed here is: what are the factors that inhibit the applicability of the Interorganizational Cost Management approach? To answer the research question, this study determined the overall goal to analyze which factors inhibit the applicability of the Interorganizational Cost Management.

Managers are facing new challenges in the pursuit of competitive advantages outside their organizations. However, they have little guidance on the potential challenges related to the implementation of approaches to Interorganizational Cost Management (Dekker, 2004; Vosselman \& Van Der Meer-Kooistra, 2006; Bastl et al., 2010). Studies that help businesses successfully implement the Interorganizational program costs can generate benefits while increasing their knowledge of business processes (Stapleton, Pati, Beach, \& Julmanichoti, 2004).

Along these lines, a diagnosis of the reasons why the Interorganizational relationships fail could contribute during all stages of building relationships, highlighting the importance of the initial phase. This analysis can help managers create statutes, formalize contracts and select chain members (especially suppliers). As such, finding out the reasons why businesses leave Interorganizational relationships can mean an improvement in their management process (Pereira et al., 2010).

\section{Theoretical Framework}

\subsection{Interorganizational Relationships}

Cooperative Interorganizational relationships are characterized by the interaction between two or more organizations, both of similar and different natures (Oliver, 1990). Businesses do not operate in isolation, but rather in contact with suppliers, customers, business partners, lenders and government agencies (Coad \& Scapens, 2006), thus, cooperation between companies is an alternative so they can increase competitiveness before the market (Ebers, 1997).

When expanding the traditional and isolated concepts of businesses, Interorganizational relationships can be configured in different ways (Zylbersztajn \& Neves, 2000). Cândido (2002) emphasizes the importance of organizations to act together, in order to adapt to the current competitive environment. Companies seek competitive advantages including the possibility of combination of competences, use of know-how from other companies, shared burden by carrying out technological research, sharing of risks and costs of exploiting new opportunities, resource-sharing and strengthening buying power, among others (Amato Neto, 2000).

\subsection{Interorganizational Cost Management}

The Interorganizational context requires that the cost management of a business not be restricted by its internal environment, as businesses are links within a chain, thus, it is influenced by external factors and, at the same time, it, too, bears an influence on chain costs. The production of goods is the result of several interconnected steps that affect one other, for the supply chain is not a sequence of independent activities, but a system of interdependent activities (Porter, 1989).

Traditional practices and management techniques do not often play the role of managing Interorganizational relationships (Bastl et al., 2010). The generation of administrative and financial information should assist managers to make decisions in that scenario (Seal, Berry, \& Cullen, 2004; Tomkins, 2001). This requires companies to manage not only their internal operations but, in unison, the operations of other chain companies (Cooper \& Slagmulder, 1999; Kulmala et al., 2002; Kajüter \& Kulmala, 2005; Coad \& Cullen, 2006; Souza \& Rocha, 2009). From this context, the Interorganizational Cost Management emerges in the area of strategic management of costs.

Interorganizational Cost Management is a structured approach to the coordination of activities of companies in a supply chain, so that its total costs are reduced (Cooper \& Slagmulder, 1999). Souza and Rocha (2009, p. 25) state that "Interorganizational Cost Management is a cooperative process of cost management comprising other organizations from a value chain besides the company itself".

IOCM aims to reduce costs related to the distribution, logistics and manufacturing of products (Cooper \& Slagmulder, 1999). The different methods for cost reduction share a focus on the coordination of businesses in the supply chain and in cost management policies across organizational boundaries, aiming at an "intelligent" cost management, so that the cooperative relations of the chain are more efficient before competitor chains (Christopher, 2007).

\subsection{Inhibiting Factors to Interorganizational Cost Management}

Companies stand to receive many benefits by coordinating efforts and acting collaboratively with members of the 
supply chain and there are many potential rewards offered justifying the creation of Interorganizational networks (Cooper \& Slagmulder 1999). However, many problems can occur during this process, which can make it difficult or impossible to achieve the goals aspired by companies.

Failures in Interorganizational relationships are recurrent and many companies are far too optimistic about the prospect of benefits when they begin in a coordination of efforts with others (Hakansson \& Snehota, 1995). This coordination can cause conflicts - common in relationships of this type -, which pose difficulties to obtaining positive results.

Bastl et al. (2010), aimed to point out the factors that inhibit the implementation of Interorganizational cost management approaches, among other goals. According to the authors, their study was the first to systematically address the inhibiting factors in the implementation of cost management approaches within the Interorganizational scope systematically. The study revealed the complexity of inhibiting factors involved in the implementation of approaches, in addition to demonstrating the interdisciplinarity of the topic.

Farias (2016) aimed to identify, in the literature, the factors and situations that inhibit the applicability of the Interorganizational Cost Management approach. In a general way, the study analyzed 35 academic studies that show the difficulties faced by companies to manage costs in a cooperative manner. The author identified 25 inhibiting factors and classified them into seven distinct groups for the purposes of analysis.

\section{Methodological Aspects}

The methodological procedures described by Farias (2016) were performed.

First, the field of exploration was delimited, and the databases selected after these steps were followed: (i) the databases which appeared in the Portal de Periódicos Capes (501 databases) were selected; (ii) in the field "Knowledge Areas", the "Social Sciences" option was specified, and the sub-area "Business Administration-Public Administration-Accounting" was chosen, which resulted in 73 databases; (iii) the databases were selected to provide "Full Text" (24 databases); and (iv) a selection was made of the databases that allowed searches on "All text fields" and the use of at least two axes by using Boolean expressions. The process resulted in 13 databases: ANNUAL REVIEWS; CAMBRIDGE JOURNALS ONLINE; EMERALD INSIGHT; JSTOR; OECD LIBRARY; SAGE JOURNALS ONLINE; APA PSYCARTICLES; WILEY ONLINE LIBRARY; PROQUEST; WEB OF SCIENCE; SCIENCEDIRECT; SCOPUS; and EBSCO.

In the selected databases, searches were conducted with terms in English, using two axes. Axis 1 contained words whose meaning is similar to "inhibitor", i.e., those words that refer to the idea of "barrier", something that gets in the way or hinders. Axis 2 contained terms related to "Interorganizational cost management".

Searches were formulated with the following keywords combined with the axes: Axis 1 - "inhibit*" OR "barrier*" OR "problem*" OR "disturb*" OR "difficult*". Axis 2 - "Interorganizational cost" OR "Interorganizational cost" OR "interorganisational cost" OR "inter-organisational cost".

The searches were conducted in January 2015, selecting the option "all text fields" using the Boolean operator "AND" between the axes, the Boolean operator "OR" between terms, without delimitation of time period.

The search was conducted in the 13 selected databases; however, there were search results in only seven databases (at least one article). The databases that provided the articles were EMERALD INSIGHT; WILEY ONLINE LIBRARY; PROQUEST; WEB OF SCIENCE; SCIENCEDIRECT; SCOPUS; and EBSCO. The search yielded a total of 418 results.

In order to ensure the relevance of the search results, the content was filtered through the following steps: (i) the 418 articles arising from the search were downloaded; however, only 225 articles were fully available and free; (ii) the 225 studies were imported into a bibliographic management software, Mendeley ${ }^{\circledR}$, which was used to delete 134 repeated or misaligned studies, thus yielding 91 works; (iii) the titles and abstracts were read, and the articles that were not aligned with the search criteria were excluded. In order to be included, a study should: a) address the issue of cost management in the Interorganizational context; b) contribute to the debate about inhibitors and barriers to Interorganizational Cost Management. After filtering, 35 studies were selected to compose the bibliographic portfolio to be analyzed.

Then, the articles were fully read. The reading of each article identified the factors that hampered/hindered Interorganizational Cost Management in each environment, enabling the creation of a report with all the identified factors. Twenty-five factors inhibiting IOMC practices were identified.

Following the phases carried out by Farias (2016), a new search started from the analysis of the references of the works comprising the bibliographic portfolio, with the aim of filling the gaps that might exist after the previous phases. Nineteen more studies were then selected. In total, 54 studies were read and 30 inhibiting factors were identified. 
In regards to the limitations of the research methods, specifically to the process carried out to identify inhibitors, the following items merit attention: a) the articles were read by a single researcher, which may have caused bias; b) the analyzed literature contains academic papers from a determined time frame (1992 - 2012); over the years, new circumstances may unfold and new inhibiting factors of the IOCM practice may be identified; and c) the use of works from different sources and in different contexts may have allowed the identification of excessively generic and comprehensive factors, without being specific to a certain branch or economic sector.

The possibilities of inhibiting factors found on the IOCM are not limited to those identified in this study. Therefore, the identified inhibiting factors and conclusions and debates on the subject may vary depending on the approach used, the methodology applied, the sector analyzed, the type of Interorganizational relationships, among others.

\section{Demonstration and Analysis of Results}

Bastl et al. (2010) suggest that the inhibitory factors that affect the cost management approaches among companies should be analyzed in three dimensions, namely: People, Process and Technology. Farias (2016) elected to group the inhibiting factors into seven groups: Corporate Strategy; Integration Between Companies; People; Intra- and Interorganizational Processes; Corporate Training and Education; Conflicts Between Companies; and Lack of Trust Between Companies. Despite the noteworthy, pioneering research emerging in regards to the subject, this study opted to classify the inhibiting factors into three groups distinct from those used by Bastl et al. (2010) and Farias (2016).

For the purposes of the present study, the 30 inhibiting factors identified were divided into three groups which refer to the developmental stages that Interorganizational relationships go through (planning, start of operations and maturation) (Ring \& Van de Ven, 1994; Bryson, Crosby, \& Stone, 2006; Chen, 2010). Group 1 is formed of inhibiting factors concerning the formation of collaborative relationships and strategies of companies. Group 2 is formed by inhibiting factors concerning the development of processes and construction of relationships. Group 3 is formed by inhibiting factors related to the results, reviews and adjustments that occur in relationships.

\subsection{Group 1 - Formation of Collaborative Relationships and Strategies of Companies}

Group 1 is formed by inhibiting factors concerning the formation of collaborative relationships and strategies of companies: it refers to the moment when companies identify opportunities and advantages that can get when they act collaboratively with suppliers and customers. At this stage, companies analyze their profiles and strategies and map opportunities and processes that can be put into practice (Miles \& Snow, 1992; Rogers, 1995; Stephenson, 2003; Shipilov, Rowley, \& Aharonson, 2006).

Table 1 shows the inhibitory factors for the Group 1.

Table 1. Inhibitory factors related the formation of collaborative relationships and strategies of companies

\begin{tabular}{|c|c|c|}
\hline & Inhibitors & Authors \\
\hline 1 & Lack of resources to execute the project & $\begin{array}{l}\text { Glad and Becker (1995); LaLonde and Pohlen (1996); } \\
\text { Nicolini, Tomkins, Holti, Oldman, and Smalley (2000); } \\
\text { Stapleton et al. (2004); Kajüter and Kulmala (2005) }\end{array}$ \\
\hline 2 & Differences between companies' strategic plans & $\begin{array}{l}\text { Hitt, Dancin, Levitas, Arregle, and Borza (2000); } \\
\text { Edelman, Bresnan, Newell, Scarborough, and Swan } \\
\text { (2004); Ojala and Hallikas (2007) }\end{array}$ \\
\hline 3 & $\begin{array}{l}\text { Different expectations of behavior between } \\
\text { companies }\end{array}$ & Hitt et al. (2000); Kajüter and Kulmala (2005) \\
\hline 4 & Lack of long-term management goals & $\begin{array}{l}\text { Messner and Meyer-Stamer (2000); Ferrin and Plank } \\
\text { (2002); Edelman et al. (2004); Möller, Windolph, and } \\
\text { Isbruch (2011) }\end{array}$ \\
\hline 5 & Dependence of mutual learning & $\begin{array}{l}\text { Ellram (2002b); Gareth (2005); Thomson and } \\
\text { Gurowka (2005) }\end{array}$ \\
\hline 6 & Lack of recognition that costing systems are necessary & Kulmala et al. (2002); Gupta and Gunasekaran (2004) \\
\hline 7 & $\begin{array}{l}\text { Lack of interest on the part of the partner companies in } \\
\text { sharing information }\end{array}$ & $\begin{array}{l}\text { Munday (1992); LaLonde and Pohlen (1996); Norek } \\
\text { and Pohlen (2001); Kulmala (2002); Kulmala et al. } \\
\text { (2002); Ellram (2002a); Cooper and Slagmulder } \\
\text { (2003a); Kulmala (2004); Agndal and Nilsson (2008); } \\
\text { Windolph and Moeller (2012) }\end{array}$ \\
\hline 8 & Lack of understanding of costs along the chain & LaLonde and Pohlen (1996); Nicolini et al. (2000) \\
\hline 9 & $\begin{array}{l}\text { Lack of perception of the value resulting from the } \\
\text { relationship }\end{array}$ & $\begin{array}{l}\text { Cooper and Slagmulder (1999); Cannon and Homburg } \\
\text { (2001) }\end{array}$ \\
\hline 10 & Difficulty in defining mutual benefits & Dekker (2003); Kajüter and Kulmala (2005) \\
\hline
\end{tabular}

Source: Survey data (2016).

Analysis of the cost behavior in the chain, project execution and construction of relationships with the members of the 
chain results in the consumption of financial resources that include, for example, labor, facilities, utilities, materials, among others, so, the lack of resources to execute the project ${ }^{1}$ could be a barrier to IOCM (LaLonde \& Pohlen, 1996; Stapleton et al., 2004). Besides the initial costs, upgrading accounting systems and maintaining relationships can require significant effort and resources (Kajüter \& Kulmala, 2005). The importance of analyzing not only the financial condition of the company, but also the other members of the chain is emphasized (Kajüter \& Kulmala, 2005).

One of the barriers to the success of coordinated actions are the differences between companies' strategic plans (Hitt et al., 2000). An understanding of the goals of partners and a compatibility with the same can improve the performance of the chain, otherwise, differences may result in conflicting relationships (Hitt et al., 2000). Before companies formalize any agreement, they may use standards and criteria for the selection of partners, analyzing the compatibility of goals and expectations (Hitt et al., 2000; Cooper \& Slagmulder, 1999).

This situation can be a barrier to Interorganizational Cost Management, so that the exchange of information and coordinated actions may be damaged (Edelman et al., 2004). Kajüter and Kulmala (2005) emphasize the importance of questioning how each party wishes to behave prior to entering into a partnership. Different expectations of behavior between companies, that is, the difference between the behavior that managers believe they would have in a possible joint action, and the expectation that they have in relation to their potential partners, could be a significant limiting factor in the implementation of IOCM (Kajüter \& Kulmala, 2005).

Companies need to signal, in a credible manner, their intentions to continue the long-term relationship when seeking to implement the IOCM (Messner \& Meyer-Stamer, 2000; Edelman et al., 2004; Möller et al., 2011). It is understood that a lack of long-term management goals could be a barrier to the approach. Being aware of the effort that exists to build the relationships and the existing delay in building trust between companies, co-coordinated management will have better results if there are long-term prospects (Ferrin \& Plank, 2002), since a commitment to long-term cost savings develops confidence between the members of the supply chain (Kajüter \& Kulmala, 2005).

Companies use the strategy of cooperation networks in order to increase their benefits however, sometimes they ignore that relations are not always synonymous with good results (Gareth, 2005). One factor that inhibits Interorganizational relationship in the long run is the fact that the partners, as they learn what others know, tend to break relations (Gareth, 2005). The partner's know-how learning can make that relationship unnecessary, leading companies leave the cooperative relationship. Thus, the dependence of mutual learning is a barrier to IOCM.

The company and its partners need to be aware of the importance of costing systems and the information generated by them. Lack of recognition that costing systems are necessary is a barrier to IOCM (Kulmala et al., 2002; Gupta \& Gunasekaran, 2004). If the company has no information on the costs available for internal use, it is impossible to share with other companies. The willingness to share information is not enough, thus, the company should assess its capacity to produce such information, since it is required a lot of work to develop costing systems (Kulmala et al., 2002).

Cooper and Slagmulder (2003a) and Kulmala (2004) explain that the relationship between buyers and suppliers must be based on confidence and great information sharing, however, companies might not be willing to share information in light of uncertainty. According to the authors, there are two measures that help reduce uncertainty, namely: the increased amount of information shared - in both directions - and the reduction of transaction processing time. Lack of interest on the part of the partner companies in sharing information can be a barrier to Interorganizational relationship (LaLonde \& Pohlen, 1996; Norek \& Pohlen, 2001; Kulmala, 2002; Ellram, 2002a).

Suppliers may reject the idea of sharing internal information due to the fear that buyers will use the data to increase the pressure on their profit margins, in an opportunistic fashion (Munday, 1992; Windolph \& Moeller, 2012). Even if the initiative to share information occurs by the buyer, the transparency of costs can bring benefits to suppliers (Agndal \& Nilsson, 2008). In this way, suppliers should be aware that information sharing, in order to conduct a strategic cost management, can bring benefits to the whole chain.

LaLonde and Pohlen (1996) and Nicolini et al. (2000) state that one of the barriers to IOCM is lack of understanding of costs along the chain by companies. Generally, companies initially develop projects and then contact the prices of suppliers who were not involved in the development of the project design.

Companies analyze the continuation, or cancellation, of relationships through the capacity of these to generate demonstrable value to the participants (Cannon \& Homburg, 2001). In fact, the reduction of the total value of the product offered to the final consumer is an indicator of the efficiency of Interorganizational relationships, but not the only one. The lack of perception of the value resulting from the relationship between companies is mentioned by Cannon and Homburg (2001) as a factor that may jeopardize the continuity of long-term relationships. The

\footnotetext{
${ }^{1}$ In the text, the inhibiting factors are highlighted in bold.
} 
measurement of the value creation, or generated intangibles, by the relationships between the companies is a difficult task, and it is their duty to appeal to a variety of perspectives to assess the value creation of relationships (Cannon \& Homburg, 2001).

Dekker (2003), Kulmala et al. (2002) and Kajüter and Kulmala (2005) identified issues related to the definition of mutual benefits as inhibitors of the practice of IOCM. They report that relationships and partnerships tend to break when they find difficulty in defining mutual benefits to the parties involved.

\subsection{Group 2 - Development of Processes and Construction of Relationships}

Group 2 is formed by inhibiting factors related to the development of processes and construction of relationships: the second stage concerns the relationships and processes carried out in order to achieve better results. At this stage, companies increase information sharing, resources and coordinate activities (Oliver, 1990). That is, the moment when planning performed in the early stage is put into practice (Nassimbeni, 1998; Olson, 1999; Prahalad \& Ramaswamy, 2004).

Table 2 shows the inhibiting factors for the Group 2.

Table 2. Inhibiting factors related to the development of processes and construction of relationships

\begin{tabular}{|c|c|c|}
\hline & Inhibitors & Authors \\
\hline 11 & Lack of trust among the partners in IOCM & Barney and Hesterly (1996); Dekker (2004) \\
\hline & & $\begin{array}{l}\text { Cooper and Yoshikawa (1994); Ellram and Siferd (1998); } \\
\text { Messner and Meyer-Stamer (2000); Nicolini et al. (2000); }\end{array}$ \\
\hline 12 & Opportunism & $\begin{array}{l}\text { Axelsson, Laage-Hellman, and Nilsson (2002); Ellram } \\
\text { (2002b); Seal et al. (2004); Edelman et al. (2004); Kajüter and } \\
\text { Kulmala (2005) }\end{array}$ \\
\hline 13 & Lack of incentives to innovate and prosper & Gareth (2005); Pereira et al., 2010 \\
\hline 14 & Resistance to change & $\begin{array}{l}\text { Ellram (1994); Ellram and Siferd (1998); Cokins (1998); } \\
\text { Axelsson et al. (2002); Lin, Collins, and Su (2001) }\end{array}$ \\
\hline 15 & $\begin{array}{l}\text { Lack of management support from members } \\
\text { of organizations }\end{array}$ & $\begin{array}{l}\text { Ellram (2002a); Seal et al. (2004); Ellram (2006); Himme } \\
(2012)\end{array}$ \\
\hline 16 & $\begin{array}{l}\text { Difficulties in integrating information } \\
\text { between companies }\end{array}$ & $\begin{array}{l}\text { Cokins (1998); Cullen, Berry, Seal, Dunlop, Ahmend, and } \\
\text { Marson (1999); Ellram (2002a, 2002b); LaLonde (2003); } \\
\text { Ramos (2004); Mouritsen and Thrane (2006) }\end{array}$ \\
\hline 17 & Unreliability of internal cost data & Ellram and Siferd (1998); Milligan (1999); Ellram (2002b) \\
\hline 18 & Inadequate level of data sharing & Munday (1992); Cooper and Slagmulder (1999) \\
\hline 19 & Poor internal availability of data & $\begin{array}{l}\text { Lin et al. (2001); Kulmala et al. (2002); Cokins (2003); } \\
\text { LaLonde (2003); Kajüter and Kulmala (2005) }\end{array}$ \\
\hline 20 & $\begin{array}{l}\text { Lack of expertise and education programs } \\
\text { geared towards employees }\end{array}$ & $\begin{array}{l}\text { LaLonde and Pohlen (1996); Cokins (1998); Cullen et al. } \\
\text { (1999); Nicolini et al. (2000); Kulmala et al. (2002); Ellram } \\
\text { (2002b); Ramos (2004); Seal et al. (2004); Thomson and } \\
\text { Gurowka (2005); Himme (2012) }\end{array}$ \\
\hline
\end{tabular}

Source: Survey data (2016).

Lack of trust among the partners in IOCM is seen as an inhibiting factor to the practice (Barney \& Hesterly, 1996; Cooper \& Slagmulder, 1999; Dekker, 2004). Cooper and Slagmulder (1999) explain that trust is the foundation of IOCM and that, once the activities begin, it should receive the necessary adjustments to its long-term maintenance. Dekker (2004) explains that even for companies that have a willingness to share information, confidence tends to be weakened when there are risks in transactions. The larger the uncertainty in agreements and partnerships, the more control mechanisms will be needed, such as the use of contracts, which increases the complexity of the relationships (Barney \& Hesterly, 1996).

Messner and Meyer-Stamer (2000) explain that opportunism is a recurrent problem in relationships. The authors consider that cooperative relationships must be based on trust among members, but even loyal members can sometimes be deceived by the partners during negotiations. The opportunistic characteristic in an Interorganizational relationship appears when one of the companies operates exclusively in pursuit of their own interests and violates rules established between the parties (Williamson, 1985). Opportunism is the breaking of agreements, standards and principles governing an Interorganizational relationship (Edelman et al., 2004), and the pursuit of exclusively individual interests when the company has cooperation agreements with others, it is unacceptable (Cooper \& Yoshikawa, 1994; Ellram \& Siferd, 1998; Dekker, 2003, Kajüter \& Kulmala, 2005).

Another barrier to the continuity of Interorganizational relationships is the lack of incentives to innovate and prosper (Gareth, 2005). A partnership between companies can insulate them from external pressure and can make them less efficient, that is, the lack of external pressures could cause the chain links to weaken. For example, according to Pereira et al., 2010, companies operating in cartel are protected from the pressures of competition, thus the excessive protection 
can cause them to fail to innovate and prosper, rendering them less efficient.

Implemented models of Interorganizational Cost Management create new scenarios, requiring new behaviors by the members of the organizations, so whenever an organization tries to change its operations, the nature and extent need to be discussed with employees (Ellram \& Siferd, 1998). The change in the organizational behavior refers not only to the matter of designing management systems, but rather be a systematic effort (Cokins, 1998; Axelsson et al., 2002). The flexibility to change is an important factor for the successful implementation of management programs, thus, resistance to change by members of organizations may be a barrier to the success of IOCM (Ellram, 1994; Ellram \& Siferd, 1998; Cokins, 1998; Axelsson et al., 2002; Lin et al., 2001).

Employees need to be encouraged to participate in all levels of the cost reduction process (Himme, 2012), since the lack of management support from members of organizations impairs the cost management (Seal et al., 2004). Companies should evaluate if managers are supported by the company's members in seeking ways to build interest in reducing costs.

Another factor that inhibits the success of IOCM are the difficulties in integrating information between companies (Cokins, 1998; LaLonde, 2003; Ramos, 2004). Ramos (2004) explains that the process of cooperation between businesses, new characteristics arise, such as increased complexity and the need to work in and outside of organizational boundaries; so, to work collaboratively requires the use of external data to the company, this requires the integration of such information.

It is important that the company's buying team be able to communicate with the internal team of suppliers, because without the support of specialists from the suppliers, the analysis may be too complex and time-consuming (Cullen et al., 1999; Ellram, 2002a, 2002b). It is expected that companies have the ability to adapt their technologies and integrate the external environment to themselves to enable the exchange of information and the application of Interorganizational Cost Management. Nevertheless, taking decisions based on information transferred by other companies can be risky, as organizations can share incorrect data "without knowing" even believing that their costing systems are efficient and provide reliable information (Milligan, 1999; Ellram, 2002b; Cokins 2003).

Milligan (1999) and Ellram (2002b) emphasize the importance of credibility of the numbers reported to the success of strategic cost management. The authors explain that the credibility of the numbers happens when all key members of the chain agree on how the figures are calculated, that is, the criteria applied. The numbers must be determined and calculated by a reliable source in order to avoid mistakes and manipulation of data (Ellram \& Siferd, 1998; Ellram, 2002b). Unreliability of internal cost data can be seen as a barrier to the success of IOCM, since management decisions are based on these (Ellram \& Siferd, 1998; Milligan 1999; Ellram, 2002b).

Munday (1992) indicates that when the shared data is used in a constructive manner, not just to pressure the margins of suppliers, the occurrence of efficient cooperation is possible. In fact, cost data, previously used only for internal report purposes, can now provide information to external partners. However, there is often inadequate level of data sharing between the companies, which can be a barrier to IOCM (Munday, 1992). In addition, poor internal availability of data is also pointed out as an obstacle to the approach (Kulmala et al., 2002; Cokins 2003; LaLonde, 2003; Kajüter \& Kulmala, 2005).

Lin et al. (2001) explain that a perfect costing system would trace all costs and activities of companies. Hundreds, even thousands, of transactions take place in a company every day, and there are activities that can only be identified and measured with significant effort of the company, which can lead to a benefit not worth its own costs. The author emphasizes that managers have to understand that the availability of internal data is a reality and that companies need to evaluate if this issue does not jeopardize the interrelationship.

Ramos (2004) points out that when the company seeks to strengthen the relationship with its suppliers, a new context arises. The environment becomes more complex; the necessity to coordinate the activities of accounting with those of logistics emerges; a need to work across organizational boundaries grows, and a drive to create new management systems, among others, comes to the forefront. In this situation, companies must evaluate if the department responsible for cost management has the competence necessary to fulfill the duties of the new context (Cokins, 1998; Cullen et al., 1999; Ramos, 2004).

Kulmala et al. (2002) explain that companies need to evaluate whether the relationships with suppliers are beneficial for their business or not. This way, they can calculate the amount of cost reduction that relationships will offer them. Toward this end, they need to have a clear understanding of cost behavior so that their analysis can illustrate whether the relationship is beneficial or not.

In order to prepare employees for the cost reduction programs, companies must provide training and education to describe the changes that may occur (Himme, 2012). Thus, the lack of expertise and education programs geared towards 
employees regarding the IOCM are regarded as barriers to the success of the approach (LaLonde \& Pohlen, 1996; Cokins, 1998; Cullen et al., 1999; Nicolini et al., 2000; Kulmala et al., 2002; Ellram, 2002b; Ramos, 2004; Seal et al., 2004; Thomson \& Gurowka, 2005; Himme, 2012).

\subsection{Group 3 - Results, Reviews and Adjustments that Occur in Relationships}

Group 3 is formed by inhibiting factors related to the results, reviews and adjustments that occur in relationship. The third stage refers to the moment when companies receive the initial results and then have the capacity to evaluate if the relationships brought benefits, and if the planning and initial goals have been achieved, so they can make the necessary adjustments to keep the relationships, if necessary (Miles \& Snow, 1992; Stephenson, 2003).

Table 3 shows the inhibiting factors for Group 3.

Table 3. Inhibitory factors related to the results, reviews and adjustments that occur in relationships

\begin{tabular}{|c|c|c|}
\hline & Inhibitors & Authors \\
\hline 21 & $\begin{array}{l}\text { Imbalance between short-term and long-term } \\
\text { gains }\end{array}$ & $\begin{array}{l}\text { Park and Ungson (2001); Edelman et al. (2004); Pereira et al. } \\
\text { (2010) }\end{array}$ \\
\hline 22 & Uneven distribution of benefits & $\begin{array}{l}\text { Cooper and Yoshikawa (1994); Cooper and Slagmulder } \\
\text { (1999); Kulmala (2004); Kajüter and Kulmala (2005); } \\
\text { Christopher (2007) }\end{array}$ \\
\hline 23 & Poorly prepared IOCM model design & $\begin{array}{l}\text { Waeytens and Bruggeman (1994); Cokins (1998, 2003); } \\
\text { Gareth (2005) }\end{array}$ \\
\hline 24 & Highly complex IOCM systems & $\begin{array}{l}\text { Cokins (1998); Messner, Meyer-Stamer (2000); Kaplan and } \\
\text { Anderson (2004) }\end{array}$ \\
\hline 25 & Inflexibility in IOCM & Park and Ungson (2001); Dubois (2003); Gareth (2005) \\
\hline 26 & Inability to determine market prices & Cooper and Slagmulder (1999); Nicolini et al. (2000) \\
\hline 27 & Loss of customer focus & Cokins (1998); Lin et al. (2001); Himme (2012) \\
\hline 28 & Unfulfilled initial goals & $\begin{array}{l}\text { Ebers (1997); Wegner and Padula (2010); Pereira, Venturini, } \\
\text { Wegner, and Braga (2010) }\end{array}$ \\
\hline 29 & Constant conflicts & $\begin{array}{l}\text { Ebers (1997); Ariño and De La Torre (1998); Messner, } \\
\text { Meyer-Stamer (2000); Kajüter and Kulmala (2005); Lui } \\
\text { (2009) }\end{array}$ \\
\hline 30 & Lack of regular performance reviews & Cooper and Slagmulder (1999); Gareth (2005) \\
\hline
\end{tabular}

Source: Survey data (2016).

Pereira et al., 2010 explain that the imbalance between short-term and long-term gains can be an inhibiting factor of the Interorganizational relationship. According to the authors, the partner companies are generally geared for the short term and the involved parties feel motivated to explore and achieve benefits quickly. However, if the partners are far too oriented to the long term, their motivation to maintain the relationship can weaken. It is thus important that the parties determine the balance between the benefits in the short and long term, in order to avoid demotivation and the erosion of the relationship.

Another obstacle to Interorganizational relationships is the uneven distribution of benefits (Cooper \& Yoshikawa, 1994; Cooper \& Slagmulder, 1999; Kulmala, 2004). Companies tend not to want to cooperate and share cost information when the benefits are not shared fairly. Christopher (2007) points out that this does not mean that the benefits should be shared equally, but that those involved are in agreement and pleased with the benefits concerning each one.

Kajüter and Kulmala (2005) explain that there is no general rule on how the benefits generated by the inter-relationship should be shared, which is justified by the fact that situations vary from case to case. Consequently, a variety of contracts has arisen, for example, the equitable sharing of benefits and the granting of benefits only for the supplier which in turn commits not to increase the price of their products -, among others (Kajüter \& Kulmala, 2005).

Waeytens and Bruggeman (1994) point out that problems in the design of models related to cost management can hamper companies from being able to determine their costs correctly and, as a result, deter collaboration with other members of their chain. A poorly prepared IOCM model design, with poorly formulated activities, which does not illustrate the real cost of the company's activities, is seen as a barrier to IOCM (Cokins, 1998, 2003; Kaplan \& Anderson, 2004; Gareth, 2005). A project poorly developed from the onset is a factor that can lead to an unsuccessful partnership (Waeytens \& Bruggeman, 1994; Cokins, 1998).

Kaplan and Anderson (2004) warn that highly complex IOCM systems can inhibit their applicability. The models implemented by companies tend to evolve while they learn more about the variety and complexity of their processes, applications, suppliers and customers. In order to increase the accuracy and details of the information, the models may become too complex, including the sharing of unnecessary information (Cokins, 1998; Messner \& Meyer-Stamer, 2000; Kaplan \& Anderson, 2004). The simpler the system and the more a company understands about the processes from their partners, the greater the potential for implementing the approach (Park \& Ungson, 2001; Kajüter \& Kulmala, 2005). 
While joint management takes place, learning about the behavior of costs succeeds, then, continuous improvements and adjustments in the relationship between companies may occur (Dubois, 2003; Gareth, 2005). Thus, the inflexibility in IOCM can lead to a problematic situation due to the dynamics and development of the needs of both partners. Relationships among companies that are too rigid or too flexible may find it difficult to achieve success (Gareth, 2005). Partners should develop a relationship in which they can mold to the changes that might occur without losing the necessary rigidity to keep the structure as otherwise agreed among the parties (Gareth, 2005).

Nicolini et al. (2000) emphasizes that the inability to determine market prices of products arising from the interrelationships could be a barrier to IOCM. According to the authors, for some products, such as commodities, the determination of prices to consumers is easier, once prices are set by the market, however, companies may have difficulties to determine the prices of other products. There are many factors that managers must consider when determining prices, for example, the price of competitors, customer characteristics, the threat of new entrants, market share, company strategies and the prices of substitute goods, among others. In other words, price determination will be subject to varying influences from companies.

Lin et al. (2001) state that companies should be alert so that there is no loss of customer focus. For the authors, companies must build their relationships based on these, as well as improve profit potential. However, management can become excessively alert to issues related to the costs in a way that they will lose focus on their customers and thus fail to meet their needs. A strategic cost management plan requires thorough planning in order to maintain the focus on the customer, for the work is useless when you lose the focus on them (Cokins, 1998; Himme, 2012).

Ebers (1997) explains that companies join efforts in order to achieve common goals, among others, to reduce costs and develop skills. According to the author, unfulfilled initial goals can lead to dissatisfaction and lack of interest in maintaining relationships. Wegner and Padula (2010) state that the continuation of Interorganizational relationships is conditioned to its ability to achieve the goals set by the companies. Failure to achieve the goals established by an Interorganizational relationship can lead to dissatisfaction and disagreement between the parties, one of the reasons why companies abandon partnerships (Ebers, 1997; Pereira, Venturini, Wegner, and Braga 2010). Furthermore, not achieving the desired initial goals can cause the conflicts, among the companies, to happen more often (Ebers, 1997).

Problems and difficulties are expected in partnerships and conflicts among the parties are a natural component to the development of relationships. Nevertheless, constant conflicts can lead to the end of the relationship (Ebers, 1997; Ariño \& De La Torre, 1998; Messner \& Meyer-Stamer, 2000; Kajüter \& Kulmala, 2005). Lui (2009) explains that relationships can end after the wear caused by conflicts, even if they have begun based on trust, goodwill from the parties, financial resources and commitment.

Gareth (2005) explains that relationships among companies must go through regular reviews, in order to make the necessary adjustments so that companies can overcome their difficulties, once the lack of regular performance reviews is seen as a barrier to a successful IOCM. Excessively stable relationships, which, in turn, do not undergo regular reviews, are also the most vulnerable to meet a definitive end.

Lastly, it bears mentioning that this study does not intend to exhaust the topic, as IOCM inhibitors vary according to the environment in which the companies operate. It is believed that diagnosing the factors that inhibit the success of Interorganizational Cost Management approach, even with the limitations that every study has, it means, in theory, to contribute to the analysis of the factors, and in practice, it means helping managers to minimize the problems that may occur in their companies.

\subsection{Discussion}

Bastl et al. (2010) suggest that the inhibitors that affect the cost management approaches between companies should be analyzed in three dimensions, namely: People, Process and Technology. Figure 1 classifies the inhibitors according to these criteria. The numbers in the figure refer to the inhibitors presented in the theoretical framework corresponding to Tables 1, 2 and 3.

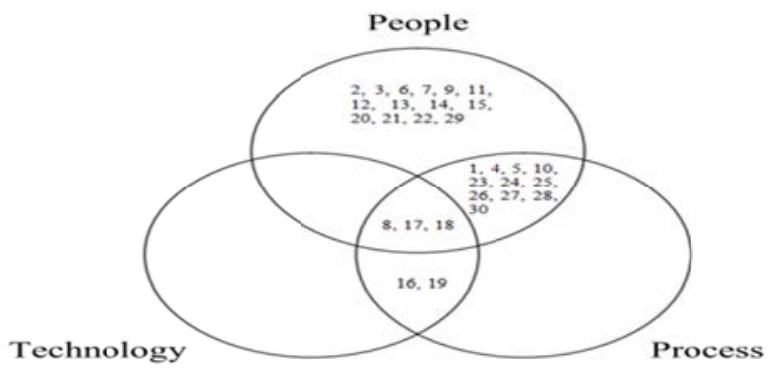

Figure 1. Inhibitors classified according to their relationship with the dimensions: People, Process and Technology 
Source: Adapted from Bastl et al. (2010)

Upon employing the perspective in Bastl et al. (2010), it can be observed that the predominant inhibitors in the companies surveyed are mainly related to People. This is to say that if Interorganizational efforts are to be successfully undertaken, the first aspect to be worked on are the people, who need to know about the importance of vision processes, information sharing, and the establishment of collaborative long-term relationships, in order to improve the performance of all companies and chains they belong to.

The use of technology and automation processes can make organizations more efficient; however, they remain predominantly dependent on actions taken by people. Companies can make specific investments in different sectors, such as technology and operational processes, so logically investments in the apprenticeship of employees can improve the organization as a whole (Barney \& Hesterly, 1996). Some behaviors, such as opportunism, resistance to change processes, lack of interest in supporting new projects, disloyalty to other companies, among others, may reflect and trigger other inhibiting factors that interfere with the success of IOCM.

Applying the classification used in this study, Table 4 shows a model which represents all identified inhibiting factors.

Table 4. Inhibitors identified in this study

\begin{tabular}{|c|c|c|c|}
\hline & Stage 1 & Stage 2 & Stage 3 \\
\hline 䒕 & $\begin{array}{l}\text { Differences between companies' } \\
\text { strategic plans } \\
\text { Different expectations of behavior } \\
\text { between companies } \\
\text { Lack of recognition that costing } \\
\text { systems are necessary } \\
\text { Lack of interest on the part of the } \\
\text { partner companies in sharing } \\
\text { information } \\
\text { Lack of perception of the value } \\
\text { resulting from the relationship }\end{array}$ & $\begin{array}{c}\text { Lack of trust among the } \\
\text { partners in IOCM } \\
\text { Opportunism } \\
\text { Lack of incentives to innovate } \\
\text { and prosper } \\
\text { Resistance to change } \\
\text { Lack of management support } \\
\text { from members of } \\
\text { organizations } \\
\text { Lack of expertise and } \\
\text { education programs geared } \\
\text { towards employees }\end{array}$ & $\begin{array}{c}\text { Imbalance between short-term } \\
\text { and long-term gains } \\
\text { Uneven distribution of } \\
\text { benefits } \\
\text { Constant conflicts }\end{array}$ \\
\hline
\end{tabular}

Lack of resources to execute the
project

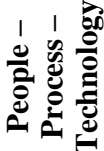

Lack of understanding of costs along the chain

\section{Poorly prepared IOCM model design \\ Highly complex IOCM systems \\ Inflexibility in IOCM \\ Inability to determine market prices \\ Loss of customer focus \\ Unfulfilled initial goals \\ Lack of regular performance reviews}

Source: Survey data (2016).

Coincidentally, it is observed that the 30 factors are equally divided into three groups: Group 1 is formed of inhibiting factors related to the formation of collaborative relationships and strategies of companies; Group 2, of inhibiting factors related to the development of processes and construction of relationships; and Group 3, of inhibiting factors related to the results, reviews and adjustments that produced by relationships. The groups indicate that inhibitors may be present at all stages of construction of relationships between companies.

As indicated previously, a strong relationship between companies based in stability, cooperation, trust and 
interdependence is a necessary component of the implementation of IOCM (Cooper \& Slagmulder, 1999; Dekker, 2003, 2004; Kajüter \& Kulmala, 2005; Souza \& Rocha, 2009; Windolph \& Moeller, 2012). Thus, managers cannot ignore the above-mentioned factors at any stage of the construction of relationships with chain members.

An interest in forming strategic partnerships must be accompanied by concerns about the protection of the companies in order to avoid or solve possible problems. The process of development of Interorganizational relationships requires, in most cases, the application of mechanisms to help regulate relationships (Cooper \& Slagmulder, 1999; Pereira et al., 2010). These are tools for planning and control used to aid the implementation of IOCM, seeking to hone, control, guide and incentivize the process (Cooper \& Slagmulder, 1999, 2003a, 2003b, 2004; Kajüter \& Kulmala, 2005; Souza \& Rocha, 2009).

Being aware that the inhibitors are present at all stages of relationships, companies must establish rules, specify rights and duties, codes of ethics and a committee that will oversee the completion of stated rules, and use mechanisms to, among other purposes, punish opportunistic behavior (Abbade, 2005; Janowicz-Panjaitan \& Noorderhaven, 2009).

As pointed out, there are many factors that influence the applicability of the IOCM, however, the factors may affect the interactions among companies in different ways. The characteristics and nuances of each organization leave them susceptible to factors in different ways. There are many characteristics of the companies that influence the applicability of management approaches, be they intra or Interorganizational in nature (Mintzberg, 1995). After all, the traits of the larger environmnet bear a great deal of influence on the applicability of IOCM (Cooper \& Slagmulder, 1999; Souza \& Rocha, 2009).

Mintzberg (1995) highlights the following characteristics in particular: a) age and size of the organization; b) technical system (formalization, technical sophistication, operational automation) used for the production of their goods or services; c) environmental characteristics in which the organization operates (dynamics, complexity and sector diversity); and d) power over the organization (considering competitors and suppliers). As such, the study emphasizes the understanding that the environment in which the company operates and its characteristics interfere with the use of management approaches.

\section{Conclusions and Recommendations}

The advantages in establishing partnerships with suppliers and customers are many, however, there are countless difficulties and factors which inhibit the relationships that aim to improve performance. The implementation of IOCM may be hampered if companies do not have the internal capabilities to achieve it. In light of this, companies must overcome internal barriers and inefficiencies first, and then undertake Interorganizational efforts.

It is concluded that Interorganizational Cost Management is an interdisciplinary phenomenon and collaborative relationships between suppliers and customers are based on many different factors. The diversity of identified inhibitors (30 factors) confirms the complexity and interdisciplinarity of the phenomenon studied. The application of the IOCM cannot be regarded as a purely technical approach, ruled by technology and management programs alone.

Most identified inhibitors relate to people, their behavior and skills. That is, before the company has well-structured processes and technologies that help in the relationship between suppliers and customers, it needs to develop its human capital. Based on this, it is concluded that, in order for companies to implement IOCM successfully, it is necessary that the people involved in the processes cooperate with the approach.

Inhibitors were found in all stages of building relationships. This suggests that the difficulties and barriers faced by managers are not restricted to a particular time, but rather occur constantly. This study stresses that managers make proactive us of mechanisms to help regulate relationships and resolve potential problems with partners.

It is expected that the identification of inhibitors contributes to reduce the risks related to the implementation of the approach, as well as risks related to the building of relationships. As a general goal, this study sought to contribute by negating the view that there are no risks and problems in the inter-relationship, from the both academy's point of view and that of managers working in the field.

It is suggested that future studies provide continuity for studies related to barriers that hinder coordination of efforts between suppliers and customers. The lack of studies on the subject is seen as a gap in the literature. Another research opportunity is the analysis of the relationship between the inhibitors of IOCM. This calls into question the existence of correlations among factors and how a given inhibiting factor affects another.

Additionally, it is also suggested that studies analyze how the strategic focus and idiosyncrasies of companies interplays with the decision to form partnerships. This analysis allows to discover if there are profiles of companies that are likely to act collaboratively with suppliers and customers. The recommendation is also made that research with an interdisciplinary approach be carried out to study mechanisms to minimize and resolve the difficulties brought by inhibitors. This can assist 
in overcoming the difficulties brought about by the larger context in which the company operates.

Finally, it is suggested that studies evaluate if IOCM inhibitors vary according to the location where the companies operate within the supply chain. Thus, it will be possible to identify which factors are common to companies that are closer to raw materials and the companies that are closer to the consumer of the chain's finished product. Along these lines, the study of Interorganizational Cost Management and the challenges encountered in their approach present opportunities for further investigation aimed at developing knowledge about the task of managing costs in an Interorganizational manner.

\section{References}

Abbade, E. B. (2005). Cooperação interorganizacional na associação londrinense de empresários supermercadistas e no APL têxtil de Goioerê: Uma análise sob a ótica da Teoria dos Custos de Transação. (Master's thesis, University of Paraná, Curitiba, Brazil). Retrieved from http://zip.net/bksHpw

Agndal, H., \& Nilsson, U. (2008). Supply chain decision-making supported by an open books policy. International Journal of Production Economics, 116(1), 154-167. http://dx.doi.org/10.1016/j.ijpe.2008.08.038

Amato, N. J. (2000). Redes de cooperação produtiva e clusters regionais: Oportunidades para as pequenas e médias empresas (3rd ed.). São Paulo, SP: Atlas.

Arino, A., \& De La, T. J. (1998). Learning from failure: Towards an evolutionary model of collaborative ventures. Organization Science, 9(3), 306-325. http://dx.doi.org/10.1287/orsc.9.3.306

Axelsson, B., Laage-Hellman, J., \& Nilsson, U. (2002). Modern management accounting for modern purchasing. European Journal of Purchasing \& Supply Chain Management, 8(1), 53-62. http://dx.doi.org/10.1016/S0969-7012(01)00017-X

Barney, J. B., \& Hesterly, W. (1996). Organizational economics: Understanding the relationship between organizations and economic analysis (1st ed.). London, UK: Sage.

Bastl, M., Grubic, T., Templar, S., Harrison, A., \& Fan, I. (2010). Inter-organisational costing approaches: The inhibiting factors. The International Journal of Logistics Management, 21(1), 65-88. http://dx.doi.org/10.1108/09574091011042188

Bryson, J., Crosby, B., \& Stone, M. M. (2006). The design and implementation of cross-sector collaborations: Prepositions from the literature. Public Administration Review, 66(1), $44-55$. http://dx.doi.org/10.1111/j.1540-6210.2006.00665.x

Cândido, G. A. (2002). A formação de redes interorganizacionais como mecanismo para geração de vantagem competitiva e para promoção do desenvolvimento regional: O papel do estado e das políticas públicas neste cenário. Revista Eletrônica de Administração, 8(4), 32-47.

Cannon, J. P., \& Homburg, C. (2001). Buyer-supplier relationships and customer firm costs. Journal of Marketing, 65(1), 29-43. http://dx.doi.org/10.1509/jmkg.65.1.29.18136

Chen, B. (2010). Antecedents or processes? Determinants of perceived effectiveness of Interorganizational collaborations for public service delivery. International Public Management Journal, 13(4), 381-407. http://dx.doi.org/10.1080/10967494.2010.524836

Christopher, M. (2007). Logística e gerenciamento da cadeia de suprimentos: Criando redes que agregam valor (2nd ed.). São Paulo, SP: Thomson Learning.

Coad, A., \& Cullen, J. (2006). Inter-organisational cost management: Towards an evolutionary perspective. Management Accounting Research, 17(4), 342-369. http://dx.doi.org/10.1016/j.mar.2006.02.003

Coad, A., \& Scapens, R. (2006). Inter-organisational cost management. Financial Management, 35(2), 38-39.

Cokins, G. (1998). Why is traditional accounting failing managers? Hospital Material Management Quarterly, 20(2), 72-80.

Cokins, G. (2003). Measuring profits and costs across the supply chain for collaboration. Cost Management, 17(5), 22-29.

Cooper, R., \& Slagmulder, R. (1999). Supply chain development for the lean enterprise: Interorganizational cost management (1st ed.). Trenton, NJ: The IMA Foundation for Applied Research.

Cooper, R., \& Slagmulder, R. (2003a). Interorganizational costing: Part 1. Cost Management, 17(5), 14-21. Retrieved from http://maaw.info/ArticleSummaries/ArtSumCooperSlagmulder03\%281\%29.htm

Cooper, R., \& Slagmulder, R. (2003b). Interorganizational costing: Part 2. Cost Management, 17(6), 12-24. Retrieved 
from http://maaw.info/ArticleSummaries/ArtSumCooperSlagmulder03\%282\%29.htm

Cooper, R., \& Slagmulder, R. (2004). Interorganizational cost management and relational context. Accounting, Organizations and Society, 29(1), 1-26. http://dx.doi.org/10.1016/S0361-3682(03)00020-5

Cooper, R., \& Yoshikawa, T. (1994). Interorganizational cost management systems: The case of the Tokyo-Yokohama-Kamakura supplier chain. International Journal of Production Economics, 37(1), 51-62. http://dx.doi.org/10.1016/0925-5273(94)90007-8

Cullen, J., Berry, A., Seal, W., Dunlop, A., Ahmend, M., \& Marson, J. (1999). Interfirm supply chains: The contribution of management accounting. Management Accounting, 77(6), 30-32.

Dekker, H. C. (2003). Value chain analysis in interfirm relationships: A field study. Management Accounting Research, 14(1), 1-23. http://dx.doi.org/10.1016/S1044-5005(02)00067-7

Dekker, H. C. (2004). Control of Interorganizational relationships: Evidence on appropriation concerns and coordination requirements. Accounting, Organizations and Society, 29(1), http://dx.doi.org/10.1016/S0361-3682(02)00056-9

Drucker, P. F. (1997). Toward the new organization. Executive Excellence, 14(2), 17-28. http://dx.doi.org/10.1002/lt1.40619970304

Dubois, A. (2003). Strategic cost management across boundaries of firms. Industrial Marketing Management, 32(5), 365-374. http://dx.doi.org/10.1016/S0019-8501(03)00010-5

Ebers, M. (1997). The formation of Interorganizational networks (1st ed.). London, UK: Oxford University Press.

Edelman, L., Bresnan, M., Newell, S., Scarborough, H., \& Swan, J. (2004). The benefits and pitfalls of social capital: Empirical evidence of two organizations in the United Kingdom. British Journal of Management, 15(1), 59-69. http://dx.doi.org/10.1111/j.1467-8551.2004.00406.x

Ellram, L. (2002a). Supply management's involvement in the target costing process. European Journal of Purchasing \& Supply Management, 8(4), 235-244. http://dx.doi.org/10.1016/S0969-7012(02)00019-9

Ellram, L. (2006). The implementation of target costing in the United States: Theory versus practice. Journal of Supply Chain Management, 42(1), 13-26. http://dx.doi.org/10.1111/j.1745-493X.2006.04201003.x

Ellram, L. M. (1994). A taxonomy of Total Cost of Ownership models. Journal of Business Logistics, 15(1), 71-191.

Ellram, L. M. (2002b). Strategic cost management in the supply chain: A purchasing and supply management perspective (1st ed.). Phoenix, AZ: CAPS Research.

Ellram, L. M., \& Siferd, S. P. (1998). Total Cost of Ownership: A key concept in strategic cost management decisions. Journal of Business Logistics, 19(1), 55-84.

Farias, R. A. S. (2016). Interorganizational Cost Management study on inhibitor. International Business Research, 9(3), 68-78. http://dx.doi.org/10.5539/ibr.v9n3p68

Ferrin, B. G., \& Plank, R. E. (2002). Total Cost of Ownership Models: An exploratory study. Journal of Supply Chain Management, 38(3), 18-29. http://dx.doi.org/10.1111/j.1745-493X.2002.tb00132.X

Gareth, B. (2005). Perfecting partnerships. Professional Engineering, 17(21), 34-44.

Glad, E., \& Becker, H. (1995). Activity-Based Costing and management (1st ed.). New York, NY: Wiley.

Gupta, K. M., \& Gunasekaran, A. (2004). Costing in new enterprise environment: A challenge for managerial accounting researchers and practitioners. Managerial Accounting Journal, 20(4), 337-357. http://dx.doi.org/10.1108/02686900510592034

Hakansson, H., \& Snehota, I. (1995). Developing relationships in business networks (1st ed.). London, UK: Routledge.

Himme, A. (2012). Critical success factors of strategic cost reduction. Metrika, 23(3), 183-210. http://dx.doi.org/10.1007/s00187-012-0157-8

Hitt, M. A., Dancin, M. T., Levitas, E., Arregle, J., \& Borza, A. (2000). Partner selection in emerging and developed market contexts: Resource-based and organizational learning perspectives. Academy of Management Journal, 43(3), 449-467. http://dx.doi.org/10.2307/1556404

Janowicz-Panjaitan, M., \& Noorderhaven, N. G. (2009). Trust, calculation, and interorganizacional learning of tacit knowledge: An organizational roles perspective. Organization Studies, 30(10), 1021-1044. http://dx.doi.org/10.1177/0170840609337933 
Kajüter, P., \& Kulmala, H. (2005). Open book accounting in networks: Potencial achievements and reasons for failures. Management Accounting Research, 16(2), 179-204. http://dx.doi.org/10.1016/j.mar.2005.01.003

Kaplan, R. S., \& Anderson, S. R. (2004). Time-Driven Activity-Based Costing. Harvard Business Review, 82(11), 131-138. http://dx.doi.org/10.2139/ssrn.485443

Kulmala, H. (2002). Open-Book Accounting in networks. Finnish Journal of Business Economics, 52(2), 157-177.

Kulmala, H. (2004). Developing cost management in cutomer-supplier relationships: Three case studies. Journal of Purchasing \& Supply Management, 10(2), 65-77. http://dx.doi.org/10.1016/j.pursup.2004.02.003

Kulmala, H., Paranko, J., \& Uusi-Rauva, E. (2002). The role of cost management in network relationships. International Journal of Production Economics, 79(1), 33-43. http://dx.doi.org/10.1016/S0925-5273(00)00061-X

LaLonde, B. (2003). Three problems that linger. Supply Chain Management Review, 7(2), 17-28.

LaLonde, B., \& Pohlen, T. (1996). Issues in Supply Chain Costing. The International Journal of Logistics Management, 7(1), 1-11.

Lin, B., Collins, J., \& Su, R. K. (2001). Supply chain activity: Na activity-based perspective. International Journal of Physical Distribution \& Logistics Management, 31(9), 702-713. http://dx.doi.org/10.1108/EUM0000000006286

Lui, S. S. (2009). The roles of competence trust, formal contract, and time horizon in Interorganizational learning. Organization Studies, 30(4), 333-353. http://dx.doi.org/10.1177/0170840608101139

Messner, D., \& Meyer-Stamer, J. (2000). Governance and networks: Tools to study the dynamics of clusters and global value chains (1st ed.). Disburg, RU: INEF.

Miles, R., \& Snow, C. (1992). Causes of failure in network organizations. California Management Review, 34(4), 53-72. http://dx.doi.org/10.2307/41166703

Milligan, B. (1999). Tracking total cost of ownership proves elusive. Purchasing, 127(3), 22-23.

Mintzberg, H. (1995). Criando organizações eficazes (1st ed.). São Paulo, SP: Atlas.

Möller, K., Windolph, M., \& Isbruch, F. (2011). The effect of rational factors on open-book accounting and inter-organisational cost management in buyer-supplier partnerships. Journal of Purchasing \& Supply Management, 17(2), 121-131. http://dx.doi.org/10.1016/j.pursup.2011.01.002

Mouritsen, J., \& Thrane, S. (2006). Accounting, network complementarities and the development of inter-organisational relations. Accounting, Organizations and Society, 31(3), 241-275. http://dx.doi.org/10.1016/j.aos.2005.04.002

Munday, M. (1992). Accounting cost data disclosure and buyer-supplier partnerships: A research note. Management Accounting Research, 3(3), 245-250. http://dx.doi.org/10.1016/S1044-5005(92)70014-6

Nassimbeni, G. (1998). Network structures and coordination mechanisms: A taxonomy. International Journal of Operations \& Production Management, 18(6), 538-554.

Nicolini, D., Tomkins, C., Holti, R., Oldman, A., \& Smalley, M. (2000). Can Target Costing be applied in the construction industry? Evidence from two case studies. British Journal of Management, 11(4), 303-324. http://dx.doi.org/10.1111/1467-8551.00175

Norek, C. D., \& Pohlen, L. (2001). Cost knowledge: A foundation for improving supply chain relationships. International Journal of Logistics Management, 12(1), 37-51. http://dx.doi.org/10.1108/09574090110806217

Ojala, M., \& Hallikas, J. (2007). Financial decision risks in supplier networks. Managing Supply Chain Risks, 8(2), 80-91. http://dx.doi.org/10.1080/16258312.2007.11517184

Oliver, C. (1990). Determinants of Interorganizational relationships: Integration and future directions. Academy of Management Review, 15(2), 241-265. http://dx.doi.org/10.5465/AMR.1990.4308156

Olson, M. (1999). A lógica da ação coletiva: Os benefícios públicos e uma teoria dos grupos sociais (1st ed.). São Paulo, SP: EDUSP.

Park, S. H., \& Ungson, G. (2001). Interfirm rivalry and managerial complexity: A conceptual framework of alliance failure. Organization Science, 12(1), 37-53. http://dx.doi.org/10.1287/orsc.12.1.37.10118

Pereira, B. A. D., Alves, J. N., \& Silva, P. E. (2010). O lado obscuro dos relacionamentos interorganizacionais: Por que as empresas saem dos processos cooperativos? Espacios, 31(4), 25-27.

Pereira, B. A. D., Venturini, J. C., Wegner, D., \& Braga, A. L. (2010). Desistência da cooperação e encerramento de redes interorganizacionais: Em que momento essas abordagens se encontram? Revista de Administração $e$ 
Inovação, 7(1), 62-83. http://dx.doi.org/10.5585/rai.v7i1.341

Porter, M. (1989). Vantagem competitiva: Criando e sustentando um desempenho superior (12th ed.). Rio de Janeiro, RJ: Elsevier.

Prahalad, C., \& Ramaswamy, V. (2004). O Futuro da competição: Como desenvolver diferenciais inovadores em parceria com os clientes (1st ed.). Rio de Janeiro, RJ: Elsevier.

Ramos, M. M. (2004). Interaction between management accounting and supply chain management. Supply Chain Management: An International Journal, 9(2), 134-138. http://dx.doi.org/10.1108/13598540410527033

Ring, P. S., \& Van de Ven, A. H. (1994). Developmental processes of cooperative Interorganizational relationships. The Academy of Management Review, 19(1), 90-118. http://dx.doi.org/10.5465/AMR.1994.9410122009

Rogers, E. (1995). Diffusion of innovations (4th ed.). New York, NY: The Free Press.

Sadowski, B., \& Duysters, G. (2008). Strategic technology alliance termination: An empirical investigation. Journal of Engineering and Technology Management, 25(1), 305-320. http://dx.doi.org/10.1016/j.jengtecman.2008.10.002

Seal, W., Berry, A., \& Cullen, J. (2004). Disembedding the supply chain: Institutionalized reflexivity and inter-firm accounting. Accounting, Organizations $\quad$ Society, $\quad 29(1), \quad 73-92$. http://dx.doi.org/10.1016/S0361-3682(02)00055-7

Shipilov, A., Rowley, T., \& Aharonson, B. (2006). When do network matter? A study of tie formation and decay. Advances in Strategic Management, 23(2), 481-515. http://dx.doi.org/10.1016/S0742-3322(06)23015-8

Souza, B. C., \& Rocha, W. (2009). Gestão de Custos Interorganizacionais: Ações coordenadas entre clientes e fornecedores para otimizar resultados (1st ed.). São Paulo, SP: Atlas.

Stapleton, D., Pati, S., Beach, E., \& Julmanichoti, P. (2004). Activity-Based Costing for logistics and marketing. Business Process Management Journal, 10(5), 584-597. http://dx.doi.org/10.1108/14637150410559243

Stephenson, G. (2003). The somewhat flawed theoretical foundation of the extension service. Journal of Extension, 41(4), 16-30.

Thomson, J., \& Gurowka, J. (2005). Sorting out the clutter. Strategic Finance, 87(2), 27-33.

Tomkins, C. (2001). Interdependencies, trust and information in relationships, alliances and networks. Accounting, Organizations and Society, 26(2), 161-191. http://dx.doi.org/10.1016/S0361-3682(00)00018-0

Vosselman, E., \& Van Der Meer-Kooistra, J. (2006). Efficiency seeking behavior in changing management control in interfirm transactional relationships: An extended transaction cost economics perspective. Journal of Accounting \& Organizational Change, 2(2), 123-143. http://dx.doi.org/10.1108/18325910610675970

Waeytens, D., \& Bruggeman, W. (1994). Barriers to successful implementation of ABC for continuous improvement: A case study. International Journal of Production Economics, 36(2), 39-52. http://dx.doi.org/10.1016/0925-5273(94)90147-3

Wegner, D., \& Padula, A. D. (2010). Governance and management of horizontal business networks: An analysis of retail networks in Germany. International Journal of Business \& Management, 5(12), 74-88. http://dx.doi.org/10.5539/ijbm.v5n12p74

Williamson, O. E. (1985). The economic institutions of capitalism (5th ed.). New York, NY: Free Press.

Wincent, J. (2008). An exchange approach on firm cooperative orientation and outcomes of strategic multilateral network participants. Group Organization Management, 33(3), 303-329. http://dx.doi.org/10.1177/1059601108318184

Windolph, M., \& Moeller, K. (2012). Open-book accounting: Reason for failure of inter-firm cooperation? Management Accounting Research, 23(1), 47-60. http://dx.doi.org/10.1016/j.mar.2011.07.001

Zylbersztajn, D., \& Neves, M. F. (2000). Economia e gestão dos negócios agroalimentares (1st ed.). São Paulo, SP: Pioneira.

\section{Copyrights}

Copyright for this article is retained by the author(s), with first publication rights granted to the journal.

This is an open-access article distributed under the terms and conditions of the Creative Commons Attribution license (http://creativecommons.org/licenses/by/3.0/). 